\section{Working conditions and musculoskeletal pain among Brazilian pottery workers}

\author{
Condições de trabalho e dor osteomuscular entre \\ ceramistas brasileiros
}

\author{
${ }^{1}$ Universidade Estadual de \\ Campinas, Campinas, Brasil. \\ Correspondence \\ A. C. S. Melzer \\ Universidade Estadual de \\ Campinas. \\ Rua Tessália Vieira de \\ Camargo 126, Campinas, SP \\ 13083-887, Brasil. \\ adrianamelzer@hotmail.com
}

\begin{abstract}
In the municipality of Pedreira in São Paulo State, Brazil, a large number of workers from the ceramic industry have left their jobs because of work related musculoskeletal disorders. The objectives of this study were to describe the work conditions pertaining to the ceramic industry, to determine the prevalence of musculoskeletal pain and to identify the associations between symptoms and organizational, biomechanical, psychosocial and individual variables. Nine ceramic manufacturers participated. The activities of 18 individuals were analyzed through direct observation. All workers answered a questionnaire about work and health $(n=235)$. The results found that the general working conditions in the pottery manufacturers were poor. A 38.5\% prevalence of musculoskeletal pain was found. Repetition, tool use, lack of control over decisions, worries regarding work demands, relationship issues, work dissatisfaction and the wish to move on to another function were all associated with pain. We concluded that musculoskeletal pain is one of the outcomes of elevated human requirements resulting from working conditions and organization in the ceramic industry.
\end{abstract}

Working Conditions; Cumulative Trauma Disorders; Musculoskeletal System
Adriana Cristina de Souza Melzer 1 Aparecida Mari Iguti ${ }^{1}$

\section{Introduction}

In Brazil, work-related musculoskeletal disorders have been the work-related disorder most frequently registered within the Social Security System (http://www.mpas.gov.br, accessed on 14/ Jun/2004). It has affected a wide range of occupational groups in several activity branches including manufacturing, services and finance. In the municipality of Pedreira in São Paulo State, workrelated musculoskeletal disorders have been the cause of a large number of sickness absenteeism and disability occurrences among workers in the ceramic industry.

In the 1980s, Pedreira become known across Brazil as The Porcelain Capital because of the number of ceramic manufacturers and variety of the products made mainly from the raw materials of clay with a mineral content, including earthenware, faience, stoneware and porcelain.

The general state of the global economy in the earlier 1990s and competition with Chinese products resulted in the closure of many factories. Those that remained began to produce household items and electric insulators. Nowadays, the municipality still has many pottery manufacturers; most produce earthenware and stoneware products such as miniatures, mugs, teacups, pots and bowls. Most of these plants are small in size.

Although there are a large number of studies published in the field of ceramic activities, all 
have focused on silicosis issues and none have addressed musculoskeletal problems.

Working conditions, including the working environment and organization, and biomechanical, psychosocial and individual factors are associated with the occurrence of musculoskeletal symptoms. All such factors have been shown in a number of studies on musculoskeletal pain among workers $1,2,3,4,5$.

The objectives of the present study were to: (a) describe the working conditions in the ceramic industry; (b) determine the prevalence of pain among active workers; (c) identify the associations between symptoms and organizational, biomechanical, psychosocial and individual variables.

\section{Methods}

\section{Setting}

From the total amount of 74 ceramic manufacturers, 33 were considered eligible. Locations with less than six workers in which all steps of the process are not developed were excluded. All of the eligible plants were contacted. Nine pottery manufacturers, all of them small, authorized the study and were included in it.

\section{Subjects and data collection}

Considering the nine plants altogether, a total of 55 workers were on sick leave, 13 of those due to musculoskeletal disorders. There were no workers on vacation.

The remaining 235 blue collar workers participated in the study. All participants answered a questionnaire on the subject of work and health. Information concerning individual profile, job history, and biomechanical and psychosocial risk factors was collected.

Questions on physical workload included incidence of repetitive movements, lifting and carrying activities, situations involving prolonged sitting or standing, movements above the shoulder level and the handling of hand tools.

Psychosocial aspects included overtime requirements, work with conveyors and machinery, work pace and demand, an individual's autonomy, relationships with colleagues and supervisors, work satisfaction, and concerns related to career advancement opportunities.

The occurrence of musculoskeletal complaints was measured using adapted questions from the Nordic Questionnaire 6. Using an illustrated body chart, the subject was asked if he/she had experienced discomfort or pain in any part of the body during the previous year. If the answer was "yes", further questions about the onset of pain, its frequency and quality were asked. Additional data collected included the possible use of medication, whether the subject saw a doctor due to the symptoms experienced and the possible causes for the discomfort or pain according to the opinion of the subject.

An additional questionnaire - Self-Reported Questionnaire (SRQ-20) 7 - was applied to 57 subjects, in order to assess the existence of minor psychological disorders. These individuals were randomly selected from those who answered the initial questionnaire.

Data about work characteristics and environment were also collected by means of direct observation. The activities of 18 subjects, two in each plant, were systematically observed, described and analyzed. The observations were conducted according to a guide proposed by McAtamney \& Corlett ${ }^{8}$. It encompasses the analysis of work aspects including organization (i.e. utilization of manual tasks or machinery work and work division), schedule (i.e. time requirements, breaks, diverse daily shifts), environmental factors (i.e. floor conditions, temperature, noise, illumination and the presence of dust), work pace evaluation (i.e. variation in pace throughout the work shift caused by performance of machinery, other workers or production demands), workstation characteristics (i.e. bench height and width), activity analysis (description, duration and repetition of each task), forceful movements (load and frequency), and body postures.

For the purpose of comparing the results, two functions were selected for the observations: manual molding, which requires filling up a mold with ceramic clay to form the parts; and honing, which involves the removal by hand of any sharp edges from each ceramic piece, before glazing.

A total of 13 visits to the nine plants took place and each one lasted no less than four hours.

All subjects were informed of the objectives of the study and signed a consent form. Information confidentiality was assured. The study was approved by the Ethics Research Committee at the Faculty of Medical Sciences of the University of Campinas.

\section{Data analysis}

Data from the interviews were summarized in descriptive statistics. Statistical analysis was performed using chi-squared testing for variables. Associations between musculoskeletal pain and independent variables were investigated by the use of the Pearson correlation coefficient with a 
significance level set at $\mathrm{p}<0.05$. The analysis was carried ou using the SPSS package, version 11.0 (SPSS Inc., Chicago, U.S.A.).

\section{Results}

Table 1 presents the characteristics of the study group according to demographic data and job history. The study group was primarily male (73.6\%), with a mean (standard deviation - SD) age of 35.6 (11.3) years, and incomplete Elementary School (61\%). The distribution of workers within the production sectors indicated that women were allocated to the finishing and decorating sectors and men to manual and mechanical molding as well as other sectors such as ceramic ovens. Mean (SD) duration of employment in the ceramic industry was 16.8 (10.6) years and mean duration of employment in the current job was 6.5 (8.5) years.

\section{The work in pottery manufacturers}

The process of pottery manufacturing is basically made up of the following steps: first, the components (clay, kaolin, quartz and feldspar) were bonded into a paste by grinding, mixing and fusing with each other; second, the paste was poured into molds to form the parts; third, the pieces were dried by passing through a stove; fourth, each part was cleaned by removing any irregular edge through manual honing with a little knife and then the part was dipped into a glaze bath which covers it completely; fifth, the parts were baked under high temperatures resulting in hard colored pieces with a vitreous surface; sixth, the pieces were decorated by manual paintings or stickers; and finally, the pieces were wrapped up and packed.

Systematic observations showed that the work at the plants analyzed was essentially manual with low inclusion of technology. The work organization followed the principles formulated by Taylor and Ford. The process was undertaken in a production line. Out of nine factories, four had mechanical conveyor belts installed in strategic sectors. The work division was based upon the different tasks allocated by who plans and who executes the work, also taking into consideration the type of activities being performed by male and female workers. Thus, production workers were restricted to the execution of repetitive and grouped tasks. Men were allocated to activities considered "heavy" such as manual and mechanical molding; consequently, they received better salaries. Women were allocated to sectors in which the work activities were considered "light" or "more deli- cate", such as finishing (including honing) and decorating the pieces. Those were in fact, more repetitive and monotonous.

In all the nine pottery manufacturers the general working environment was poor. The floor was irregular and uncovered, acting as a source of dust and giving rise to accidents. There was a high level of noise from the operation of the kilns, stoves and machinery. Additionally only a few workers in one of the factories used ear plugs. These operations also led to a raised temperature, a situation that is aggravated during the summer because of the lack of ventilation in production areas. Illumination was inadequate due to the failure of many light bulbs and because the spaces in the roof designed to provide natural light were too small and insufficient in number. Despite government efforts to control the dust in the ceramic industry, we observed that this was still a problem: the workers remained exposed to high levels of silica without any individual or collective protection.

The assessment of the work activities in manual molding and honing showed that both involve repetitive movements of the upper extremities, and honing was highly repetitive. Mechanical conveyors were detected only among workers in the finishing area, where the work pace was more elevated. The work in molding was made up by a higher number of activities in relation to finishing, which means that the work in the latter was more monotonous. Also, the workers in molding had more autonomy to make decisions regarding their jobs. Finishing workers remained mainly in a static standing position throughout the working day, while in molding the workers were requested to walk along a workbench.

\section{Workers' perceptions about working conditions}

Table 2 shows relevant characteristics of the work according to the workers' perceptions.

The daily working time in the pottery industry was 8 hours and 48 minutes, from Monday to Friday, with no rest breaks. Taking into consideration all workers, $52 \%$ stated that they worked overtime (53\% female and $48.5 \%$ male), which means an additional one or two hours per day and/or work for four hours on Saturdays. For those who worked overtime, $31 \%$ of them stated that they "seldom" work overtime, and $21 \%$ stated that they work overtime "every day".

Among the female workers, $51 \%$ attested that they work with mechanical conveyors, against $16 \%$ of the male workers. On the other hand, $55 \%$ of males attested that they work with machinery, against $8 \%$ of the females. 
Characteristics of the study group according to demographic data and job history. Pedreira, São Paulo State, Brazil.

\begin{tabular}{|c|c|c|c|c|}
\hline \multirow[t]{2}{*}{ Characteristics } & \multicolumn{2}{|c|}{ Female $(N=173)$} & \multicolumn{2}{|c|}{ Male $(\mathrm{N}=62)$} \\
\hline & $\mathrm{n}$ & $\%$ & $\mathbf{n}$ & $\%$ \\
\hline \multicolumn{5}{|l|}{ Age (years) } \\
\hline$<18$ & 2 & 1.0 & 1 & 1.5 \\
\hline $19-26$ & 35 & 20.0 & 14 & 22.5 \\
\hline $27-34$ & 57 & 33.0 & 11 & 18.0 \\
\hline $35-42$ & 38 & 22.0 & 11 & 18.0 \\
\hline $43-50$ & 32 & 18.5 & 13 & 21.0 \\
\hline $51-58$ & 5 & 3.0 & 6 & 9.5 \\
\hline$>58$ & 4 & 2.5 & 6 & 9.5 \\
\hline \multicolumn{5}{|l|}{ Level of education } \\
\hline Incomplete Elementary School & 108 & 62.5 & 35 & 58.0 \\
\hline Elementary School graduate & 19 & 11.0 & 8 & 13.0 \\
\hline Incomplete High School & 14 & 8.0 & 6 & 9.5 \\
\hline High School graduate & 30 & 17.5 & 10 & 16.0 \\
\hline Illiterate & 2 & 1.0 & 2 & 3.5 \\
\hline \multicolumn{5}{|l|}{ Working sector } \\
\hline Manual molding & 18 & 10.5 & 25 & 40.0 \\
\hline Mechanical molding & 1 & 0.5 & 15 & 24.0 \\
\hline Finishing & 95 & 55.0 & 2 & 3.5 \\
\hline Decorating & 37 & 21.0 & 1 & 1.5 \\
\hline Packaging & 18 & 10.5 & 2 & 3.5 \\
\hline Others & 4 & 2.5 & 17 & 27.5 \\
\hline \multicolumn{5}{|l|}{ Time in ceramic industry (years) } \\
\hline$<1$ & 13 & 7.5 & 5 & 8.0 \\
\hline $1 \mid-3$ & 24 & 14.0 & 8 & 13.0 \\
\hline $3 \mid-8$ & 53 & 30.5 & 7 & 11.5 .0 \\
\hline $8 \mid-12$ & 20 & 11.5 & 8 & 13.0 \\
\hline $12 \mid-21$ & 38 & 22.0 & 15 & 24.0 \\
\hline $21 \mid-30$ & 22 & 13.0 & 9 & 14.5 \\
\hline$>30$ & 3 & 1.5 & 10 & 16.0 \\
\hline \multicolumn{5}{|l|}{ Time in current job (years) } \\
\hline$<1$ & 41 & 23.5 & 6 & 9.5 \\
\hline $1 \mid-3$ & 37 & 21.5 & 14 & 22.5 \\
\hline $3 \mid-8$ & 62 & 36.0 & 14 & 22.5 \\
\hline $8 \mid-12$ & 14 & 8.0 & 6 & 9.5 \\
\hline $12 \mid-21$ & 14 & 8.0 & 12 & 19.0 \\
\hline $21 \mid-30$ & 5 & 3.0 & 3 & 5.0 \\
\hline$>30$ & 0 & 0.0 & 7 & 11.5 \\
\hline
\end{tabular}

The work pace was considered fast for $47.5 \%$ of all workers and repetitive for $90 \%$. Among female workers, $48.5 \%$ attested that they had to work in a fast pace and $91.5 \%$ that their work was repetitive. Among male workers, $45 \%$ reported that they had to work in a fast pace and $87 \%$ that their work was repetitive.
In terms of the biomechanical aspects of work, $84 \%$ of all workers $(82.5 \%$ of females and $88.5 \%$ of males) revealed that they work standing during all the working day and they were not allowed to change their postures, $58 \%$ (63\% of females and $43.5 \%$ of males) revealed that they perform lifting and carrying activities, 56\% (61\% of females and $42 \%$ of males) that they carry out 
Table 2

Characteristics of working in the pottery industry, by sex. Pedreira, São Paulo State, Brazil.

\begin{tabular}{|c|c|c|c|c|}
\hline \multirow[t]{2}{*}{ Characteristics } & \multicolumn{2}{|c|}{ Female $(N=173)$} & \multicolumn{2}{|c|}{ Male $(\mathrm{N}=62)$} \\
\hline & n & $\%$ & $\mathrm{n}$ & $\%$ \\
\hline \multicolumn{5}{|l|}{ Overtime working } \\
\hline Yes & 92 & 53.0 & 30 & 48.5 \\
\hline No & 81 & 47.0 & 32 & 51.5 \\
\hline \multicolumn{5}{|c|}{ Working with mechanical conveyors } \\
\hline Yes & 89 & 51.0 & 10 & 16.0 \\
\hline No & 84 & 49.0 & 52 & 84.0 \\
\hline \multicolumn{5}{|c|}{ Working with machinery } \\
\hline Yes & 14 & 8.0 & 34 & 55.0 \\
\hline No & 159 & 92.0 & 28 & 45.0 \\
\hline \multicolumn{5}{|c|}{ Required fast work pace } \\
\hline Yes & 84 & 48.5 & 28 & 45.0 \\
\hline No & 89 & 51.5 & 34 & 55.0 \\
\hline \multicolumn{5}{|l|}{ Repetitiveness } \\
\hline Yes & 158 & 91.0 & 54 & 87.0 \\
\hline No & 15 & 9.0 & 8 & 13.0 \\
\hline \multicolumn{5}{|c|}{ Working in a standing position } \\
\hline Yes & 143 & 82.5 & 55 & 88.5 \\
\hline No & 30 & 17.5 & 7 & 11.5 \\
\hline \multicolumn{5}{|l|}{ Lifting/Carrying } \\
\hline Yes & 109 & 63.0 & 27 & 43.5 \\
\hline No & 64 & 37.0 & 35 & 56.5 \\
\hline \multicolumn{5}{|c|}{ Movement above shoulder level } \\
\hline Yes & 106 & 61.0 & 26 & 42.0 \\
\hline No & 67 & 39.0 & 36 & 58.0 \\
\hline \multicolumn{5}{|l|}{ Using hand tools } \\
\hline Yes & 104 & 60.0 & 19 & 30.5 \\
\hline No & 69 & 40.0 & 43 & 69.5 \\
\hline \multicolumn{5}{|l|}{ Decision latitude } \\
\hline Yes & 17 & 10.0 & 7 & 11.5 \\
\hline No & 156 & 90.0 & 55 & 88.5 \\
\hline \multicolumn{5}{|c|}{ Worries regarding work demands } \\
\hline Yes & 57 & 33.0 & 10 & 16.0 \\
\hline No & 116 & 67.0 & 52 & 84.0 \\
\hline \multicolumn{5}{|c|}{ Good relationship with colleagues } \\
\hline Yes & 169 & 97.5 & 60 & 96.5 \\
\hline No & 4 & 2.5 & 2 & 3.5 \\
\hline \multicolumn{5}{|c|}{ Good relationship with supervisors } \\
\hline Yes & 165 & 95.0 & 62 & 100.0 \\
\hline No & 8 & 5.0 & 0 & 0.0 \\
\hline \multicolumn{5}{|l|}{ Work satisfaction } \\
\hline Yes & 169 & 97.5 & 61 & 98.5 \\
\hline No & 4 & 2.5 & 1 & 1.5 \\
\hline \multicolumn{5}{|c|}{ Wish to move on to another function } \\
\hline Yes & 6 & 3.5 & 2 & 3.5 \\
\hline No & 167 & 96.5 & 60 & 96.5 \\
\hline \multicolumn{5}{|c|}{ Believe in career promotion } \\
\hline Yes & 23 & 13.5 & 7 & 11.5 \\
\hline No & 150 & 86.5 & 55 & 88.5 \\
\hline
\end{tabular}


movements above shoulder level, and 52.5\% ( $60 \%$ of females and $30.5 \%$ of males) that they use hand tolls.

Concerning psychosocial aspects, $90 \%$ of all workers $(90 \%$ of females and $88.5 \%$ of males) attested that they did not participate in decision processes regarding their jobs, $28.5 \%$ (33\% of females and $16 \%$ of males) admitted that they had worries regarding their work load, $98 \%$ (97.5\% of females and $98.5 \%$ of males) attested that they were satisfied with their jobs, $96.5 \%$ (96.5\% for both females and males) that they did not wish to move on to another function, and $87 \%$ ( $86.5 \%$ of females and $88.5 \%$ of males) declared that they did not believe in work promotions. Relationships with colleagues were considered good for $97.5 \%$ of all workers $(97.5 \%$ of females and $96.5 \%$ of males) and relationships with supervisors were considered good for $96.5 \%$ of all workers $(95 \%$ of females and $100 \%$ of males).

\section{Occurrence of musculoskeletal pain}

A $38.5 \%(n=90)$ prevalence of musculoskeletal pain over the past 12 months was found. Among female workers the prevalence was $46 \%(n=80)$ and among their male counterparts it was $16 \%$ $(\mathrm{n}=10)$.

The distribution of complaints throughout the age groups was similar, varying from $41 \%$ to $46 \%$ between the ages of 35 and 50 . Among the production sectors, finishing was the sector with the highest number of workers with musculoskeletal pain $(52.5 \%)$, followed by manual molding (39.5\%), packing (25\%), "other sectors" (24\%), painting (23.5\%) and mechanical molding (18.5\%).

Of the 90 workers who experienced musculoskeletal pain, 57 (63.5\%) mentioned one site, $18(20 \%)$ two, 9 (10\%) three, 4 (4.5\%) four, and 2 (2\%) mentioned five different sites. The most affected locations were lower limbs (35\%) and back (33\%), followed by neck (9\%), shoulders $(9 \%)$, hand/wrists $(9 \%)$, elbows $(3.5 \%)$, and thoracic region $(1.5 \%)$.

Considering the onset of symptoms, $52.5 \%$ answered that they experienced pain for more than a year prior to the interview, $31 \%$ between two months and one year prior to the interview, $4.5 \%$ for less than a month and $12 \%$ did not know.

Regarding the frequency of the pain episodes, $48 \%$ admitted that they felt pain every day, $20 \%$ every week but not every day, and $32 \%$ seldom. The period of the day in which the pain is more exacerbated was at afternoons for $67.5 \%$, at nights for $15.5 \%$, at mornings for $4 \%$, and all day long for $13 \%$.
For the majority of the workers suffering from musculoskeletal pain, it had not interfered with their duties or activities outside work, or with the sleeping time. Among those who presented symptoms, $41 \%$ needed medication for pain relief, $49 \%$ sought medical advice and $5.5 \%$ took sick leave.

Out of the 57 individuals who answered the SRQ-20, 37\% presented scores equal to or lower than 7 , which indicated the presence of minor psychiatric disorders.

\section{Associations between variables and musculoskeletal pain}

Table 3 shows the associations between the studied variables and musculoskeletal pain.

A significant relationship was found between musculoskeletal pain and female gender. Among the biomechanical and psychosocial variables, repetition, tool use, lack of control over decisions, worries regarding work demands, relationship issues with supervisors, work dissatisfaction and the desire to move on to another function were all associated with symptoms.

\section{Discussion}

The cross-sectional study design could have led to the occurrence of selection/survivor bias, such as the healthy worker effect, as mentioned by other studies 9,10,11. This can explain the fact that musculoskeletal pain was not associated with time on the job. Additionally, it is possible that the high number of workers on sick leave could have created a "survivor's effect", causing remaining workers to underestimate existing risk factors 12 .

Information bias may also have occurred since most data was based on self-reports 13 . Some authors, however, have established the advantages of this approach as long as it is used in association with other techniques, such as direct measurements or the direct observation method 14,15 .

The adoption of a 12-month period to evaluate the occurrence of pain can also lead to problems of memory 16. Despite its limitations, the $38.5 \%$ prevalence of pain founded in this study is consistent with studies carried out in different occupational groups. Prevalence from 20 to $40 \%$ of pain was found among active carpenters in United States 11, 34\% among office workers in Finland 17, 35\% among nurses in England 18, 37\% of back pain among workers in the shipyard industry in Greece 13 , and $45 \%$ of pain among office workers in Germany 19. 
Table 3

Associations between variables and musculoskeletal pain. Pedreira, São Paulo State, Brazil.

\begin{tabular}{|c|c|c|c|c|}
\hline \multirow[t]{2}{*}{ Variables } & \multicolumn{2}{|c|}{ Prevalence } & \multirow[t]{2}{*}{$\chi^{2}$} & \multirow[t]{2}{*}{ p-value } \\
\hline & $\mathbf{n}$ & $\%$ & & \\
\hline $\operatorname{Sex}(n=90)$ & & & 17.516 & $<0.001$ \\
\hline Female & 80 & 89.0 & & \\
\hline Male & 10 & 11.0 & & \\
\hline Age group (years) $(n=90)$ & & & 8.795 & 0.932 \\
\hline$<18$ & 0 & 0.0 & & \\
\hline $19-26$ & 16 & 18.0 & & \\
\hline $27-34$ & 29 & 32.0 & & \\
\hline $35-42$ & 20 & 22.0 & & \\
\hline $43-50$ & 21 & 23.5 & & \\
\hline $51-58$ & 1 & 1.0 & & \\
\hline$>58$ & 3 & 3.5 & & \\
\hline Level of education $(n=90)$ & & & 4.138 & 0.290 \\
\hline Incomplete Elementary School & 57 & 63.5 & & \\
\hline Elementary School graduate & 12 & 13.5 & & \\
\hline Incomplete High School & 9 & 10.0 & & \\
\hline High School graduate & 10 & 11.0 & & \\
\hline Illiterate & 2 & 2.0 & & \\
\hline Time in ceramic industry (years) $(n=90)$ & & & 8.464 & 0.675 \\
\hline$<1$ & 3 & 3.5 & & \\
\hline $1 \mid-3$ & 11 & 12.0 & & \\
\hline $3 \mid-8$ & 26 & 29.0 & & \\
\hline $8 \mid-12$ & 15 & 16.5 & & \\
\hline $12 \mid-21$ & 20 & 22.0 & & \\
\hline $21 \mid-30$ & 12 & 13.5 & & \\
\hline$>30$ & 3 & 3.5 & & \\
\hline Time in current job (years) $(n=90)$ & & & 6.483 & 0.601 \\
\hline$<1$ & 18 & 20.0 & & \\
\hline $1 \mid-3$ & 20 & 22.0 & & \\
\hline $3 \mid-8$ & 30 & 33.5 & & \\
\hline $8 \mid-12$ & 7 & 8.0 & & \\
\hline $12 \mid-21$ & 10 & 11.0 & & \\
\hline $21 \mid-30$ & 5 & 5.5 & & \\
\hline$>30$ & 0 & 0.0 & & \\
\hline Working sector $(n=90)$ & & & 17.781 & 0.096 \\
\hline Manual molding & 17 & 19.0 & & \\
\hline Mechanical molding & 3 & 3.5 & & \\
\hline Finishing & 51 & 56.5 & & \\
\hline Painting & 9 & 10.0 & & \\
\hline Packing & 5 & 5.5 & & \\
\hline Others & 5 & 5.5 & & \\
\hline Minor psychiatric disorders $(n=34)$ & & & 24.077 & 0.009 \\
\hline$\geq 7$ & 18 & 53.0 & & \\
\hline$<7$ & 16 & 47.0 & & \\
\hline Repetition $(n=90)$ & & & 4.716 & 0.030 \\
\hline Yes & 86 & 95.5 & & \\
\hline No & 4 & 4.5 & & \\
\hline
\end{tabular}

(continues) 
Table 3 (continued)

\begin{tabular}{|c|c|c|c|c|}
\hline \multirow[t]{2}{*}{ Variables } & \multicolumn{2}{|c|}{ Prevalence } & \multirow[t]{2}{*}{$\chi^{2}$} & \multirow[t]{2}{*}{ p-value } \\
\hline & $\mathbf{n}$ & $\%$ & & \\
\hline Lifting/Carrying activities $(n=90)$ & & & 0.001 & 0.982 \\
\hline Yes & 52 & 42.0 & & \\
\hline No & 38 & 58.0 & & \\
\hline Movements above shoulder level $(n=90)$ & & & 0.869 & 0.363 \\
\hline Yes & 54 & 60.0 & & \\
\hline No & 36 & 40.0 & & \\
\hline Handling of hand tools $(n=90)$ & & & 18.235 & $<0.001$ \\
\hline Yes & 63 & 70.0 & & \\
\hline No & 27 & 30.0 & & \\
\hline Working overtime $(n=90)$ & & & 0.535 & 0.467 \\
\hline Yes & 44 & 49.0 & & \\
\hline No & 46 & 51.0 & & \\
\hline Working with conveyors $(n=90)$ & & & 7.512 & 0.006 \\
\hline Yes & 48 & 53.5 & & \\
\hline No & 42 & 46.5 & & \\
\hline Working with machinery $(n=90)$ & & & 1.268 & 0.262 \\
\hline Yes & 15 & 16.5 & & \\
\hline No & 75 & 83.5 & & \\
\hline Fast pace $(n=90)$ & & & 8.905 & 0.003 \\
\hline Yes & 54 & 60.0 & & \\
\hline No & 36 & 40.0 & & \\
\hline Autonomy $(n=90)$ & & & 3.450 & 0.064 \\
\hline Yes & 5 & 5.5 & & \\
\hline No & 85 & 94.5 & & \\
\hline Worry with work demands $(n=90)$ & & & 13.455 & $<0.001$ \\
\hline Yes & 38 & 42.0 & & \\
\hline No & 52 & 58.0 & & \\
\hline Relationship with colleagues $(n=90)$ & & & 0.064 & 0.801 \\
\hline Good & 88 & 98.0 & & \\
\hline Bad & 2 & 2.0 & & \\
\hline Relationship with supervisors $(n=90)$ & & & 13.898 & $<0.001$ \\
\hline Good & 82 & 91.0 & & \\
\hline Bad & 8 & 9.0 & & \\
\hline Believe in career promotion $(n=90)$ & & & 3.259 & 0.072 \\
\hline Yes & 7 & 8.0 & & \\
\hline No & 83 & 92.0 & & \\
\hline Work satisfaction $(n=90)$ & & & 8.231 & 0.004 \\
\hline Yes & 85 & 94.5 & & \\
\hline No & 5 & 5.5 & & \\
\hline Wish to move on to another function & & & 4.721 & 0.030 \\
\hline Yes & 6 & 6.5 & & \\
\hline No & 84 & 93.5 & & \\
\hline
\end{tabular}


Lower limbs have been a very common site of pain among industry worker populations and it is related to working in standing positions for extended periods without posture variations 20,21. Studies have shown that prolonged standing is associated with discomfort and cardiovascular problems and have postulated the benefits of changing posture while working 22 . Back pain can also be related to working in standing positions, and to activities which require lifting/carrying loads and repetitive movements of the upper limbs 23,24. Neck, shoulder and upper limb pain have been related to work activities which require holding the neck in a forward bent posture for a prolonged time, working with arms above shoulder level and repetitive movements of hands and wrists $25,26,27$. Those aspects were identified in the work activities among pottery workers.

The higher percentages of workers with pain that seek medication and that have seen a doctor because of the pain indicates that the workers are enduring work with pain. They choose not to leave their jobs until their individual limit has been reached and working and daily living activities have been impaired.

The prevalence of minor psychiatric disorders was high, considering other studies with workers carried out in Brazil, such as the $19 \%$ prevalence found among metallurgists, and the $10 \%$ prevalence among workers in the paper industry 28,29 . It suggests that working in the pottery industry also affects the mental health of workers.

The study emphasized the role of the work organization in the development of symptoms, as well as the interaction among biomechanical, psychosocial and individual variables. Features of work organization in the pottery industry such as a fast pace and overtime work are associated with chronic outcomes such as musculoskeletal symptoms. This is supported by some authors 30,31 .

The fact that women displayed a higher prevalence for pain is related to a clear work division according to gender identified in the pottery industry. Some authors have defended its relation emphasizing that in the gender division of work, women are allocated to highly repetitive, monotonous and less autonomous work tasks 32,33,34.

Among biomechanical factors, repetition has been identified as one of the most important risk factors for work-related musculoskeletal disorders. Despite the fact the present study found that lifting or carrying weights was not associated with musculoskeletal complaints, it is important to consider its synergic effect with repetition, since the working sector with the higher rate of repetition also had the higher rate of lifting/ carrying activities 35 . Studies have also shown that using hand tools that are not ergonomically designed can lead to direct compression of the muscles, to the adoption of awkward postures and to forceful pinching, leading to musculoskeletal pain 36 .

Recent studies that consider the diversified nature of work-related musculoskeletal disorders have emphasized the role of psychosocial factors in its development or aggravation. Among those factors, high work demands, lack of control over working activities, poor social support from the supervisors and colleagues, and work dissatisfaction have been associated with symptoms 23,26,37,38.

\section{Conclusions}

Musculoskeletal pain is one of the outcomes of elevated human demands resulting from the work conditions and organization that prevail in the pottery industry. Women were shown to have a higher prevalence of symptoms because they are mostly allocated to sectors in which the pace is more accelerated, tasks are repetitive and monotonous, job control is minimal, and work postures are stationary. People are working with pain. Seeking medical advice is delayed until the worker's individual limit is reached. Medication ends up as the only alternative found by workers to carry on with their duties. 


\section{Resumo}

No Município de Pedreira, São Paulo, Brasil, um grande número de trabalhadores das indústrias cerâmicas se afasta do trabalho em conseqüência de distúrbios osteomusculares relacionados ao trabalho. Os objetivos deste estudo foram descrever as condições de trabalho, determinar a prevalência de dor e identificar associações entre sintomas e variáveis organizacionais, biomecânicas, psicossociais e individuais. Nove indústrias participaram do estudo. As atividades de 18 pessoas foram analisadas através de observações diretas. Todos os trabalhadores responderam a um questionário sobre trabalho e saúde $(n=235)$. Os resultados indicaram que as condições de trabalho nas indústrias cerâmicas estudadas eram ruins. Foi encontrada uma prevalência de 38,5\% de dor. Repetitividade, utilização de instrumentos de trabalho, falta de autonomia para decisões, preocupação com a produção, problemas de relacionamento, insatisfação no trabalho e desejo de mudar de função foram associadas à dor. Concluiu-se que a dor osteomuscular é uma das conseqüências do elevado custo humano derivado das condições e da organização do trabalho nas indústrias cerâmicas.

Condições de Trabalho; Transtornos Traumáticos Cumulativos; Sistema Musculosquelético

\section{References}

1. Nahit ES, Macfarlane GJ, Pritchard CM, Cherry NM, Silman AJ. Short term influence of mechanical factors on regional musculoskeletal pain: a study of new workers from 12 occupational groups. Occup Environ Med 2001; 58:374-81.

2. Guo H-R. Working hours spent on repeated activities and prevalence of back pain. Occup Environ Med 2002; 59:680-98.

3. Chen J-C, Dennerlein JT, Shih T-S, Chen C-J, Cheng Y, Chang WP, et al. Knee pain and driving duration: a secondary analysis of the taxi-drivers health study. Am J Public Health 2004; 94:575-81.

4. Kerr MS, Frank JW, Shannon HS, Norman RW, Wells RP, Neumann WP, et al. Biomechanical and psychosocial factors for low back pain at work. Am J Public Health 2001; 91:1069-75.

\section{Contributors}

A. C. S. Melzer was responsibel for the research and for writing the article. A. M. Iguti participated actively in reading and revising the article.
5. Andersen JH, Kaergaard A, Mikkelsen S, Jensen UF, Frost P, Bonde JP, et al. Risk factors in the onset of neck/shoulder pain in a prospective study of workers in industrial and service companies. Occup Environ Med 2003; 60:649-54.

6. Kuorinka I, Jonsson B, Kilbom A. Standardized Nordic Questionnaires for the analysis of musculoskeletal symptoms. Appl Ergon 1987; 18:233-7.

7. Almeida OP. Sintomas psiquiátricos entre pacientes com demência atendidos em um serviço ambulatorial. Arq Neuropsiquiatr 1999; 57:937-43

8. McAtamney I, Corlett EN. Reducing the risks of work upper limb disorders: a guide and methods. Nottingham: The Institute of Occupational Ergonomics, University of Nottingham; 1992. 
9. Punnett L, Robins JM, Wegman DH, Keyserling WM. Soft tissue disorders in the upper limbs of female garment workers. Scand J Work Environ Health 1985; 11:417-25.

10. Chiang H-C, Ko Y-C, Chen S-S, Yu H-S, Wu T-N, Chang P-Y. Prevalence of shoulder and upperlimb disorders among workers in the fish-processing industry. Scand J Work Environ Health 1993; 19:126-31.

11. Lemasters GK, Atterbury MR, Booth-Jones AD, Bhattacharya A, Ollila-Glenn N, Forrester C, et al. Prevalence of work related musculoskeletal disorders in active union carpenters. Occup Environ Med 1988; 55:421-7.

12. Silverstein BA, Fine LJ, Armstrong TJ. Hand wrist cumulative trauma disorders in industry. $\mathrm{Br} \mathrm{J}$ Ind Med 1986; 43:779-84.

13. Alexopoulos EC, Tanagra D, Konstantinou E, Burdorf A. Musculoskeletal disorders in shipyard industry: prevalence, health care use, and absenteeism. BMC Musculoskelet Disord 2006; 7(88). http://www.biomedcentral.com/bmcmusculosk eletaldisord/ (accessed on 29/Jan/2007).

14. Burdorf A, van der Beek A. Exposure assessment strategies for work-related risk factors for musculoskeletal disorders. Scand J Work Environ Health 1999; 25 Suppl 4:25-30.

15. Kilbom A. Assessment of physical exposure in relation to work-related musculoskeletal disorderswhat information can be obtained from systematic observations? Scand J Work Environ Health 1994; 20:30-45.

16. Björkstén MG, Boquist B, Tallbäck M, Edling C. The validity of reported musculoskeletal problems. A study of questionnaire answers in relation to diagnosed and perception of pain. Appl Ergon 1999; 30:325-30.

17. Korhonen T, Ketola R, Toivonen R, Luukkonen R, Häkkänen M, Viikari-Juntura E. Work related and individual predictors for incident neck pain among office employees working with video display units. Occup Environ Med 2003; 60:475-82.

18. Smedley J, Inskip H, Trevelyan F, Buckle P, Cooper C, Coggon D. Risk factors for incident neck and shoulder pain in hospital nurses. Occup Environ Med 2003; 60:864-9.

19. Cagnie B, Danneels L, Van Tiggelen D, De Loose V, Cambier D. Individual and work related risk factors for neck pain among office workers: a cross sectional study. Eur Spine J 2007; 16:679-86.

20. Gamperiene M, Stigum H. Work related risk factors for musculoskeletal complaints in the spinning industry in Lithuania. Occup Environ Med 1999; 56:411-6.

21. Orlando AR, King PM. Relationship of demographic variables on perception of fatigue and discomfort following prolonged standing under various flooring conditions. J Occup Rehabil 2004; 14:63-76.

22. Laperrièrre E, Ngomo S, Thibariet MC, Messing K. Indicators for choosing an optimal mix of major working postures. Appl Ergon 2006; 37:349-57.
23. Andersen JH, Haarhr JP, Frost P. Risk factors for more severe regional musculoskeletal symptoms: a two year prospective study of a general working population. Arthritis Rheum 2007; 56:1355-64.

24. Xiao GB, Dempsey PG, Lei L, Ma ZA, Liang YX. Study on musculoskeletal disorders in a machinery manufacturing plant. J Occup Environ Med 2004; 46:341-6.

25. Palmer KT, Smedley J. Work relatedness of chronic neck pain with physical findings: a systematic review. Scand J Work Environ Health 2007; 33:165-91.

26. Johnston V, Jimmieson NL, Souvlis T, Jull G. Interaction of psychosocial risk factors explain increased neck problems among female office workers. Pain 2007; 129:311-20.

27. Punnett L, Gold J, Katz JN, Gore R, Wegman DH. Ergonomic stressors and upper extremity musculoskeletal disorders in automobile manufacturing: a one year follow up study. Occup Environ Med 2004; 61:668-74.

28. Borges LH, Faria MAM. Transtornos mentais menores entre trabalhadores de uma usina siderúrgica. Rev Bras Saúde Ocup 1993; 21:7-18.

29. Fassa AG, Facchini LA, Dall'Agnol MM. Trabalho e morbidade comum em indústria de celulose e papel: um perfil segundo setor. Cad Saúde Pública 1996; 12:297-307.

30. Johnston V, Lipscomb J. Long working hours, occupational health and the changing nature of work organization. Am J Ind Med 2006; 49:921-9.

31. Ghisleni AP, Merlo ARC. Trabalhador contemporâneo e patologias por hipersolicitação. Psicol Reflex Crít 2005; 18:171-6.

32. Antunes R. Adeus ao trabalho? Ensaio sobre as metamorfoses e a centralidade do mundo do trabalho. 7ạ Ed. São Paulo: Cortez Editora/Campinas: Editora da Unicamp; 2000.

33. Hirata H. Reestruturação produtiva, trabalho e relações de gênero. Revista Latino-Americana de Estudos do Trabalho 1998; 4:5-27.

34. Leclerc A, Chastang J-F, Niedhammer I, Landre M-F, Roquelaure Y. Incidence of shoulder pain in repetitive work. Occup Environ Med 2004; 61:39-44.

35. Viikari-Juntura E, Kurppa K, Kuosma E, Huuskonen M, Kuorinka I, Ketola R, et al. Prevalence of epicondylitis and elbow pain in the meat-processing industry. Scand J Work Environ Health 1991; 17: 38-45.

36. Dong H, Loomer P, Barr A, Laroche C, Young E, Rempel D. The effect of tool handle shape on hand muscle load and pinch force in a simulated dental scaling task. Appl Ergon 2007; 38:525-31.

37. Bongers PM, Ijmker S, van den Heuvel S, Blatter BM. Epidemiology of work related neck and upper limb problems: psychosocial and personal risk factors (part I) and effective interventions from a bio behavioural perspective (part II). J Occup Rehabil 2006; 16:279-302.

38. Fjell Y, Alexanderson K, Karlqvist L, Bildt C. Selfreported musculoskeletal pain and working conditions among employees in the Swedish public sector. Work 2007; 28:33-46.

Submitted on 04/May/2009

Final version resubmitted on 03/Nov/2009

Approved on 18/Dec/2009 